\title{
NARRATIVES ON THE ORIGIN OF THE INSTITUTION OF THE MUFTIATE AMONG TATARS IN SOVIET TIMES
}

\author{
R.I. Bekkin \\ Institute of Oriental Studies \\ at the Herzen State Pedagogical University of Russia \\ St. Petersburg, Russian Federation \\ Institute for African Studies, Russian Academy of Sciences \\ Moscow, Russian Federation \\ bekkin@mail.ru
}

The rationale behind the creation of the institution of the muftiate in 1788 in Ufa was that the state wanted to better control the spiritual life of Muslims in the Russian Empire and use it as a tool for implementing domestic and foreign policy. It seemed more convenient for the government to deal with an organized structure incorporated into the system of state-controlled institutions rather than with separate, non-institutionalized representatives of Muslims who relied mainly on their authority among faithful and did not need legitimation and support from the state (either financial or legal). A certain number of Muslim religious figures also did not initially accept this institution. However, by midnineteenth century the Muslim community came to the understanding that it needed the institution of the muftiate through which they could represent and defend their interests relative to the state and the Synodal Church as a governmental body.

Moreover, the Tatars began viewing the spiritual assembly in Ufa as a national institution guarding Tatar national identity within the context of the Orthodox state. The Tatar population of the empire thus appropriated the muftiate, giving rise to the legend that the institution had historically existed among the Tatars long before they were conquered by the Russians.

The first narratives that the muftiate existed in the Kazan Khanate and was destroyed after the conquest of Kazan in 1552 probably appeared at the end of the nineteenth century. In Soviet times, this point of view was widespread in the 1920-1930s. Later it was modified and subsequent aspects of the narrative emphasized some aspects of the history of the muftiate, and concealed others. But the main thesis that the muftiate is an important institution for preserving the spiritual culture of the Tatar people remained unchanged. These changes in the interpretation of its history became in many ways a reflection of the processes that took place in the system of Soviet muftiates and, above all, in the Central Spiritual Administration of Muslims in Ufa in Soviet times.

This point of view contradicted the views of a number of Soviet historians (Lyutsian I. Klimovich, Arshaluis M. Arsharuni, Hadzhi Z. Gabidullin, Galimjan G. Ibragimov and others), who considered the muftiate an exclusively colonial institution imposed on Muslims and serving as an instrument of enslavement and oppression.

Keywords: muftiate, the Orenburg Mohammedan Spiritual Assembly, Rizaeddin Fakhreddin, Faizrakhman Sattarov, Islam in the USSR 
For citation: Bekkin R.I. Narratives on the Origin of the Institution of the Muftiate among Tatars in Soviet times. Istoricheskaya etnologiya, 2020, vol. 5, no. 2, pp. 225-242. https://doi.org/10.22378/he.2020-5-2.225-242

\section{Introduction}

With the loss of statehood by Tatars in the middle of the sixteenth century the Islamic scholars ('ulama') started to play the role of not only religious but political leaders of the Volga-Ural region. In the eighteenth century, the intentions of the imperial authorities, which sought to bring the religious life of its minority populations under control, coincided with the above-named processes. This led to the formation of the so-called 'Muslim clergy' as a special social group within the spiritual estate of the Russian Empire.

On the other hand, in late eighteenth-early twentieth century, the opposite trend can also be observed. Representatives of the two ideologically opposed camps - some state bureaucrats, missionaries and hierarchs of the Orthodox Church on the one hand, and unofficial Islamic religious leaders on the other criticized the institutionalization of the ministers of the Islamic religion.

In the eyes of the former, the muftiate (established in 1788 under the name of the Ufa Spiritual Mohammedan Law Assembly (Ufimskoe dukhovnoe magometanskogo zakona sobranie), later known as the Orenburg Mohammedan Spiritual Assembly (Orenburgskoe Magometanskoe Dukhovnoe Sobranie, OMDS), acted as a tool for consolidating Muslims and strengthening the position of Islam in the empire. For the latter, the Spiritual Assembly in Ufa was an instrument for the state for controlling the religious life of the followers of Islam. The paradox is that these two critical views on the muftiate did not contradict but complemented each other. The muftiate was indeed conceived and implemented as an instrument of control over Muslims, and it continued to fulfill this function until the fall of the monarchy. At the same time, however, it acted as a consolidating center for Tatars living in the European part of the country and Siberia.

The following factors also contributed to the strengthening of the role of OMDS as a national institution for the Tatars: a) the policy of the imperial authorities, which sought to prevent the expansion of the influence of OMDS outside the Tatar communities (especially since $1860 \mathrm{~s}$ ), ${ }^{1}$ b) the personnel policy of

${ }^{1}$ From the very first yeas of the existence of the institution of the muftiate the Russian authorities relied on it as a promoter of the Russian influence among Kazakh population. As the Russian historian Irina A. Rechkina argues, the Russian government consciously facilitated the strengthening and spread of Islam in Kazakh Steppe. This policy was aimed at preventing the influence of Bukhara emirate and Khiva khanate (Rechkina 2006: 80). In 1868 the religious affairs of Kazakhs (Kyrgyzes in the terminology of that time) were removed from the scope of the jurisdiction of OMDS. These questions were referred to the competence of local mullahs who in turn were subordinate to the civil administration and the Ministry of Internal Affairs. 
the muftis who employed Tatars in the muftiate. Thus by limiting the sphere of influence of OMDS to only the Tatar-Muslim population, the authorities, indirectly contributed to the transformation of the muftiate into a national institution for the Tatars and strengthened their national identity.

It seemed more convenient for the government to deal with an organized structure incorporated into the system of state-controlled institutions rather than with separate, non-institutionalized representatives of Muslims who relied mainly on their authority among faithful and did not need legitimation and support from the state (either financial or legal). In addition, the costs associated with the creation and upkeep of the muftiate seemed to be less than the money that would have been spent in bribes in order to take control of individual religious figures. Baron Iosif Igelström, the author of the muftiate project ${ }^{2}$, directly wrote about this: "As a reward for this small expense [680 silver rubles a year. R.B.] all the local peoples upholding the Mohammedan law, when they realize hereby the extent to which the faith is respected in Your Majesty's empire, will be all the more devoted and steadfast" (Yunusova, Azamatov 2013: 26).

That is, the main outcome of Catherine's reforms in the Islamic sphere was that holding a position in the system of state institutions rather than enjoying authority among believers became the primary source of legitimacy for Muslim religious leaders. In Max Weber's terminology, the charismatic authority of Muslim religious leaders was replaced by bureaucratic authority (Turner 2006: 23). It should be noted that the transition from one type of legitimacy to another did not occur at once but took almost half a century.

However, despite the restrictions that akhuns, imams and mullahs faced because of the campaign for the institutionalization of the Muslim clergy, the establishment of the muftiate at that stage was undoubtedly a progressive step. It was not the creation of OMDS itself that mattered but the fact that it was one of the necessary steps towards giving Islam the status of a tolerated religion instead of the status of a persecuted (unrecognized) faith which it had possessed since 1552 when Muscovite Rus' annexed the Kazan Khanate. In other words, the institutionalization and bureaucratization of Islam became the price Muslims of the Russian Empire paid to the state to legitimize it. It was a bargain for all parties. Being forced to operate in the new legal environment, the ministers of the Islamic religion managed to make the most of the rights they were granted by imperial legislation.

A certain number of Muslim religious figures also did not initially accept this institution. However, by mid-nineteenth century the Muslim community came to the understanding that it needed the institution of the muftiate through which they could represent and defend their interests relative to the state and the Synodal Church as a governmental body. Moreover, the Tatars began viewing the Spiritual Assembly in Ufa as a national institution guarding Tatar national identity within

${ }^{2}$ Some authors suppose that the idea of the muftiate was proposed by Dmitri B. Mertvago (1760-1824), who served as advisor to the Ufa provincial administration (Zagidullin 2011: 4). 
the context of the Orthodox state. The Tatar population of the empire thus appropriated the muftiate, giving rise to the legend that the institution had historically existed among the Tatars long before they were conquered by the Russians.

The first narratives that the muftiate existed in the Kazan Khanate and was destroyed after the conquest of Kazan in 1552 probably appeared at the end of the nineteenth century. One can only guess what caused the emergence of these narratives. If not the chief, then one of the main reasons was the desire of the Turkic-Tatar authors to substantiate the idea that the institution of the muftiate had its roots among the Muslims of the Volga-Ural region. It seemed important to them to emphasize that the muftiate was not a colonial institution, but a national one created by the Muslims themselves. This point of view was widespread in the early Soviet times during 1920-1930s. Later it was modified and subsequent aspects of the narrative emphasized some aspects of the history of the muftiate, and concealed others. But the main thesis that the muftiate is an important institution for preserving the spiritual culture of the Tatar people remained unchanged. These changes in the interpretation of its history became in many ways a reflection of the processes that took place in the system of Soviet muftiates and, above all, in the Central Spiritual Administration of Muslims of Inner Russia and Siberia (Tsentral'noe Dukhovnoe Upravlenie Musul'man Vnutrenney Rossii i Sibiri), established in 1920 in Ufa.

In this article I investigate two texts produced by Islamic religious figures in Soviet time: the memorandum of Mufti Rizaeddin Fakhreddin compiled in 1923 and the sermon of the imam-khatib of the Leningrad Cathedral Mosque Faizrakhman Sattarov dedicated to the fiftieth anniversary of the October Revolution (1967).

\section{Rizaeddin Fakhreddin: "The Russian government... constantly ran into opposition from the Muslim clergy and, naturally, oppressed it by all measures"}

The Orenburg Mohammedan Spiritual Assembly, which a number of Muslim religious figures initially perceived as hostile, began over time to be viewed as a primordially national institution, if not for all Tatars, then at least for those who lived in the Volga-Ural region. This is reflected in narratives dating back to the twentieth century that are part of the so-called "Islamic discourse." According to the German Islamic studies scholar Reinhard Schulze, Islamic discourse comprises "all media, institutions, linguistic statements and symbols deliberately using a vocabulary and a sign system which convey concepts of the Islamic tradition" (Schulze 2002: 9).

One of the key elements of the narratives about the Spiritual Assembly as the primal national institution of Tatars of the Volga-Ural region is the legend that the muftiate had existed long before the eighteenth century. Thus in the nineteenth-century composition Tawarikh Bulgaria (Bulgarian Chronicles), the author, a Tatar historian by the name of Khusain Amirkhanov, writes that at 
least the post of mufti was known in the Kazan Khanate (Amirkhanov 2010: 87). However, this statement may result from a misconception of the term "mufti" that came into use among Muslims of the Volga-Ural region in a later era (the late eighteenth century). In other words, Amirkhanov could have called muftis religious figures who in fact had other titles. Unfortunately, not all materials that could shed light on the history of religious life in the Kazan Khanate have been put into circulation, and the scanty information we do have only allows us to learn about the place which Islamic religious figures occupied in the system of government in the Kazan Khanate. ${ }^{3}$

To the best of my knowledge, the first mention of this legend in texts authored by Muslims dates back to the early Soviet era, specifically, to a Memorandum by Mufti Rizaeddin Fakhreddin (Ridha al-Din Fakhr al-Din) sent to the Presidium of the All-Russian Central Executive Committee (VTsIK) ${ }^{4}$ on behalf of the Central Spiritual Administration of Muslims of Inner Russia and Siberia:

Following the adoption of Islam, the Turkic peoples of the Volga and Urals organized their Spiritual Administration with the posts of mufti, qazis, mullahs and muezzins. This form of organization of the Spiritual Administration of Muslims existed before they were conquered by Ivan the Terrible [my emphasis. - R.B.]. Russian tsars, intolerant of all non-Christian religions, completely destroyed the Spiritual Administration and destroyed the prayer houses ... Despite such oppression, the Muslims of the Volga and Ural regions completely preserved their religion and their spiritual organization, although in an illegal, underground form (Arapov 2010: 40).

The above extract introduces several important ideas:

1) The muftiate was known to the Muslims of the Volga-Ural region long before Russian rule, and, therefore, this institution is not a product of imperial bureaucracy.

2) The muftiate continued its existence after the fall of the Kazan Khanate in an "underground form"; that is, it was a body in opposition to the current government.

A similar interpretation by the leadership of TsDUM of the history of spiritual administration among the Tatars is the result of a well-thought-out strategy of relations with the highest state authority in Soviet Russia - the Presidium of the All-Russian Central Executive Committee. The author of the Memorandum (perhaps it was a collective author) had the task of convincing Soviet officials "to allow schoolchildren under eighteen years of age to study in groups in mektebs, mosques, and general civilian school buildings outside Muslim classroom hours" (Arapov 2010: 44). In addition, it was necessary to protect

${ }^{3}$ I am grateful for this reference to the historian Azat M. Akhunov from Tatarstan.

${ }^{4}$ All-Russian Central Executive Committee (VTsIK) - supreme legislative, administrative and regulatory body of state power in the Russian Soviet Federative Socialist Republic in 1917-1937. 
the Spiritual Administration from oppression by the republican authorities (particularly the leadership of the Bashkir Autonomous Soviet Socialist Republic, in whose capital TsDUM was located).

The spiritual administration in Ufa acted as an intermediary between Moscow and Muslim citizens. Being limited in its rights, TsDUM, represented by the mufti, used the opportunity to defend the interests of Muslims. In particular, in some cases the appeals of the mufti on behalf of TsDUM to the authorities responsible for the implementation of confessional policy in Moscow helped to cancel or mitigate decisions of the authorities of the national republics directed against the muftiate and believers.

The author of the Memorandum indicates that the muftiate had nothing to do with the administrative institutions of the tsarist regime, but arose in Volga Bulgaria $\left(10-13\right.$ centuries). ${ }^{5}$ This state itself is not mentioned, but the phrase "after the adoption of Islam organized their Spiritual Administration" refers to the indicated historical period. The legend put forward in the Memorandum that the institution of the muftiate was created precisely in Volga Bulgaria and not later (under the Golden Horde or the Kazan Khanate) has its own explanation. The Memorandum was compiled in 1923, when the Golden Horde and the Kazan Khanate were still considered, in accordance with the traditions of prerevolutionary historical science, as feudal states hostile to Muscovite Rus' ${ }^{6}$ At the same time, the attitude toward Volga Bulgaria of Russian and then Soviet historians in the early 1920s was more neutral than hostile. Thus, whoever drew up the Memorandum or advised its author had a good idea of the addressees, namely representatives of the new government who spoke the language of class struggle. That is why "the Muslim clergy" in the Memorandum are presented as an oppressed group under the tsarist regime and the muftiate is described as a national institution that defended the interests of the masses and fought against the chauvinistic Russification policy pursued by tsarist officials:

The Russian government, pursuing an embarrassing policy [among] the foreigners of Russia, constantly ran into opposition from the Muslim clergy and, naturally, oppressed it by all measures. The only support of the Muslim clergy came from the popular masses: the clergy, closely uniting with the people, taught them religion, literacy and always consoled them in difficult days. It is appointed by the people themselves. All the ministers of the Islamic religion were always chosen by believers and were responsible to them. They do not receive a salary. The population pays them in a strictly voluntary manner as much as they can for the performance of spiritual rituals. The rural clergy is engaged in ordinary peasant farming (Arapov 2010: 42).

${ }^{5}$ See Rashid I. Malikov's work, which holds that the Muslim clergy as a separate social stratum probably formed in Volga Bulgaria (Malikov 2013: 29).

${ }^{6}$ For more details on the perception of the history of the Kazan Khanate in Soviet historical science, see, for example: (Khamidullin et al. 2012). 
The author of the Memorandum is silent about the fact that the mufti and assessors (qazis) received good salaries from the state and were incorporated into the system of the imperial state bureaucracy. He only writes about mullahs and other notable ministers of religion, who indeed depended materially on the community that elected them (mahallah). Being the representatives of the peasant estate (social class) themselves, the mullahs were not only materially but also, due to their origin, closely connected with the masses. The imams are singled out as Muslim clergy, but they just did not fall into this category. "The Muslim clergy" comprised a small privileged group of Muslim bureaucracy that included the mufti and members of the board of the muftiate (qazis). Neither does the author of the Memorandum mention about the role of assistants and allies of the Russian authorities which the Tatars - the ministers of the Islamic religion played in the colonization of the Kazakh Steppe.

Thus, the author of the Memorandum is telling the truth, as it were, but only part of the truth. Strictly speaking, in the context of communist ideology, the muftis, who were fairly affluent, were as oppressive as other representatives of the tsarist administration (Arapov 2010: 42). The Memorandum deliberately obscured this fact, noting only the following:

One of the issues that had been worrying and displeasing the Muslim population was the appointment of the mufti and qazis. They were appointed by the Russian government. Muslims constantly protested against this, demanded permission to choose the mufti and qazi and, along with this, separation of the church from the state (Arapov 2010: 42).

As a matter of fact, the question of separating the church from the state was not raised either by the spiritual authorities or by Muslims until 1917. However, the decree "On the Separation of the Church and the State, and the School from the Church" of 1918 was indeed met with enthusiasm by a significant number of Muslims. The qazis of TsDUM, including Mufti Fakhreddin, cooperated with the Soviet government. Therefore, it was important for the mufti to emphasize the completely different role the Spiritual Administration on the one hand and the ministers of the Islamic religion on the other hand played in the Russian Empire and in Soviet Russia. In summary, this role was formulated as follows: in tsarist Russia, the clergy protected the people from oppression by the authorities, and in Soviet Russia the Spiritual Administration acted as a natural ally of the Soviet government in the "political and economic liberation of the Muslim peoples of the East" (Arapov 2010: 42).

Quite naturally in the eyes of the author of the Memorandum, the muftiate promoted "the establishment of necessary calm among the Muslim population, recognition and good will towards the Soviet government, the power of workers and peasants" (Arapov 2010: 43). Indeed, if under the monarchy the Muslim clergy raised their voices in defense of the disadvantaged, now it could not but act as a natural ally of the regime which spoke on behalf of the underprivileged.

The Memorandum of 1923 is also of particular interest because Mufti Rizaeddin Fakhreddin, whose signature appears under the typewritten text, was 
known in pre-revolutionary years for his criticism of OMDS in his book Government Orders Relating to Muslims (Fakhreddin 1902: 9-10). The main emphasis in his criticism was that OMDS showed excessive zeal in promoting the interests of the Russian state among Muslim subjects of the empire.

\section{Faizrakhman Sattarov: "there were no organizations for conducting religious affairs"}

Another important element of the narrative about the muftiate that was formed in the Soviet era was the myth about the disenfranchised position of the ministers of the Islamic religion in the Russian Empire. Thus in 1967 the imamkhatib of the Leningrad Cathedral Mosque Faizrakhman Sattarov (1929-2015) noted in his sermon dedicated to the fiftieth anniversary of the October Revolution how many benefits Muslims received from the Soviet government. ${ }^{7}$ Among other things, he touched on the role of the muftiate, contrasting the position of the Spiritual Administration in tsarist Russia with its current position in the USSR. Evidence of the dismissive attitude of the imperial authorities towards Islam was that "there were no organizations for conducting religious affairs" (Bekkin 2018: 302).

He goes on to note:

True, in 1788 the tsar allowed the organization of a religious center called the Spiritual Assembly of Islam in Ufa. About a hundred years later [in] 1872, it was allowed to create a Muslim religious center in Transcaucasia. ${ }^{8}$ However, these organizations were only formal, because the ministers appointed to head these centers were not allowed to do anything. The ceremony of marriage, divorce, naming, everything was in the hands of the tsarist government (Bekkin 2018: 302).

At first glance it might seem that these extracts from the 1923 Memorandum and the Sermon of 1967 containing an interpretation of the history of the muftiate strongly contradict one another. In fact, however, the texts are mutually complementary. The Memorandum states that the muftiate was a primordial national institution known even to the ancestors of the modern Tatars, and that it was then organized once again already in imperial times. The Sermon says nothing about the period preceding the Russian conquest of the Kazan Khanate, but it is clear from its text that the creation of the muftiate in Ufa was a kind of concession of tsarism to Muslims. This statement does not contradict the text of the Memorandum, whose author tries to talk less about the muftiate during the imperial period and more about it before the Russian conquest. At the same time, Sattarov, like the author of the Memorandum, strongly emphasizes the institution is needed for the normal functioning of Islam. The Sermon therefore reproaches the imperial authorities for not creating the muftiate or an organiza-

\footnotetext{
${ }^{7}$ For a detailed analysis of this Sermon, see: (Bekkin 2018).

${ }^{8}$ This refers to the Transcaucasian Mohammedan Spiritual Directorates of Sunni and Shia Teachings.
} 
Bekkin R.I. Narratives on the Origin of the Institution of the Muftiate among Tatars in Soviet times

tion similar to it for a long time (according to the Memorandum, the muftiate existed in the sixteenth-eighteenth centuries, albeit illegally, but this narrative was either not known to Sattarov, or was ignored by him).

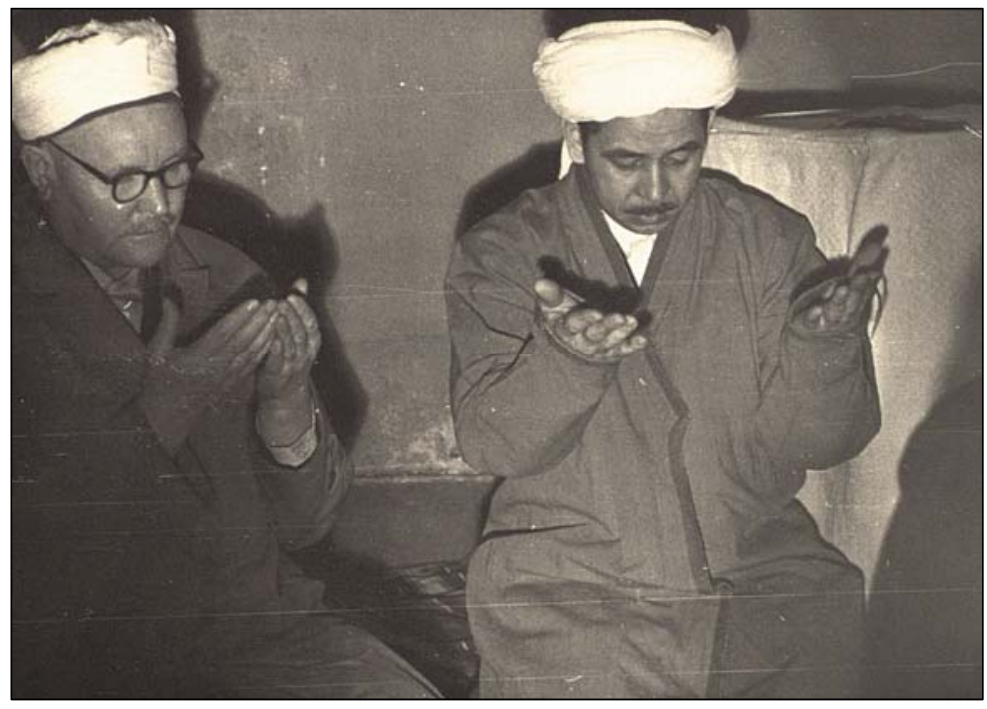

Imam-khatib Faizrakhman Sattarov (at the center) at prayer in the Leningrad Cathedral Mosque, 21 April 1967. To his left is muezzin Musa Nemeshev.

Photo by D.I. Iskakov (Courtesy the State Museum of the History of Religion)

Even after 1788, Sattarov notes, the muftiate could not be regarded as a full-fledged representative of the aspirations of Muslims oppressed by the Romanov monarchy. It was a fictitious organization that did not have any rights and opportunities. The Spiritual Administration in Ufa, according to the Sermon, did not have any opportunity to conduct even the main rites, not to mention represent the interests of Muslims vis-à-vis government officials. And it was not until the Soviet regime, according to Sattarov, that Muslims acquired the right to have an organization that fully corresponded to their aspirations.

Needless to say, most statements in the sermon concerning the religious life of Muslims before 1917 do not stand comparison with reliable sources. In 1967, when the text we are considering was prepared, these sources were not available to most believers who listened to Sattarov. Among the parishioners of the Leningrad Cathedral Mosque there were, however, many living witnesses of the pre-revolutionary era. These people remembered what happened after October, when Muslim religious leaders fell into the category of "disenfranchised", that is, were deprived of many civil and social rights. How they perceived the words contained in the sermon that the imams were not allowed to carry out religious rituals before the October Revolution is anyone's guess. 
Initial sheets (1-4) of a typewritten copy of Faizrakhman Sattarov's Friday sermon, read on the occasion of the 50th anniversary of the Great October Socialist Revolution, 1967 (Courtesy the State Museum of the History of Religion)

\section{Увахаемве иусудьмане! \\ (Поздравдение пятницей.)}

Увағаеме цусудьмане поздравпяю Вас настунавщим днем великого праздника, днем исподнения - 50-детия дибмого Советского государства, днөм приносящи равенство и свободу всөм народам намего государства. Да вдравствует день одершавщий победы Ведивой Октябрьскон Социадистическон реводюции. Да ниспошдет Адлах нам и нашим поколениям в будущем встречать дөнь в которое сдөдала первые паги наше дорогое дюбимое государство, как ми өго встречаөм сегодня вел дикими успехами й наивысший достияниями.

Јважаөмые иусудьмане, өсди позводит Адлах, мы сегодня усдьшим в чөсть торгөственного праздника О Вепикой Социадистичөской рөвопиции, которое нам принесла вечнур радость.

Сегодня речь будөт посвещена пологении рөдигии в царское время, и о великои развитии редигии посде установдения Советской Власти。 На соновании дед которое вөдет духовное управпение иусудьшан и из истории очевидцами которой явдяется старшее покодение. Иввестно что в царское время подоженге цусульман было очень, очег плохии. Офцциадъно признанной релитией считалось только хрпстианство. На редигио исдама нпкакого внимания не обращали, на оборот редиги исдама смотреди пршрениеи униянием. Дагө ддя вөдения редигиовного дела ни каких организаций не было. Нравда в I788 году быно разрешөно царем организовать редигиовный центр нод названиеи Духовное Собрание ислама в гор.Уфе. Примерно сто дет спустя І872 году было разрешөно создать мусудьманский редигиовный девтр в вакавказьии. Однако эти органиаации быди только формальнкии, потоиу что поставленньи во гдаве әтих дентров сдухителям ничего не позводядось дөдать. Обряд бдакосочетания, развод, наречения имии 
Bekkin R.I. Narratives on the Origin of the Institution

of the Muftiate among Tatars in Soviet times

\section{$-2-$}

все быдо в руках царского правительства. Почет слущитедям цудьта оказывади меньще, чем рядовым чиновникам.

До І868 г. в гор.УФе правдение Оренбургского духовенства не имедо помещения. Все редигиозные дөда вөдись тодько на русскои явыке. Даже когда В I889 году отмечадось ІОО дөтие создания Управдения Оренбургского духовенства не быдо разрешения говорить ни на каком явыке кроме русского. Потому что согдасно уставу все религновнье дела проходили под контродем административных властей царского рехима5 Все проповеди сводидись к прославленио пиераторая хеданиеи өиу дөлгой ечастливой хизни.

Такте никакого увагения нө имеди руноводство пркходе в седьских местах. Их брапи даже не военнур спугбу и сборы, тогда как представителей других религшй не брали ни когда. Судхители других редигий подучади жадование, а цусудьманским сдущителям получать хадование от подаяния не разрешапи. Приход помогал по уере возмошности. В годы годода народ подучад опредеденный паек ог государства, а мудлу обходили. घто васается образованияб только дворянские и захиточные семьи могди дать обравование своим детям. Бөдному хе вухно быдо работать как дапти чиновника присдугон у них на доиу। Сказаннои пророком I400 дет назад что учеба для хенщия и мудчин обязательно они понятия не имеди. Но дюдяи пониающее әто, показапось не решимой пробпеиой. Таким образом матери и сестры быди дишены от в8ятия карандаша в руки. Названная пророком хөнщина подругой хизни, своецу цуху раздедяощая все успехи, радости, счастия и не ввгоды ни в нескодьких года, а на вечно нецогла написать одну строчву писька своеку дорогому иуху или кавадеру отдавая одну монету водота.

В царское время цусудьмане Северного Кавказа Туркестанской обдасти (" тадхики, казахи, киргияы, туркмены и узбеки) до I905 r. 
были соверенно забитыми народвии. У них небыло ни какого редигиоввого обдественного органа, они вөди свои редигиовные деда, как умеди.

I905 г. царское правитедьство, хөдая осдабить Оренбургское Духовное Управдение в г.УФе, прикавадо объеденить его со Среднөазиатскии Духовным Управдениеи и выработать проект нового устава. Однако, сиогдасно этому проекту, цусудьманө, нө подучив никаких прав, оказапись под наи болеө сильним контролем.

Мусудьмане и религиовные сдудитөли кудьта не доводьные с әтим проектои постоянно вели споры раздоры до Ведикой Октяб рьской реводиции.

Похогие на это ивдеватепьство и гнета со стороны царя не тодько в пути редитии, но и в другой области очень очень мого они перехивади суровне времена и никак не мотди освободиться от них гнета.

Однако таким унихениям, цучениям приел однахды конец. Под руководством ведикого вохдя Денина в I9I7 году Великая Октябрьская Социалистическая ревопюция одөрғала победу и установина Великое Советское государство, которое явняется образцовыи приером своими достихениями. Опдотом установденш мира во всем мире, и права, равенство, свободу всөи народащ. Как только установидась Советская вдасть, редигиознке дела быни упорядочены согласно шариату

2Іъго января I9I8 г. состоялись выборы нового цуфтги и казыөз Первым цуфттеи был Казанец-Голиц- тан ишан Годиев. иусудъманское Управление Оренбургской губернии получидо название Духовного упрах дения России и Сибири.

Духовное управление оставвлось центрадьным органои религии ислама. Органивовадись органивадии мухтасибов и имамов приходах. 
Bekkin R.I. Narratives on the Origin of the Institution of the Muftiate among Tatars in Soviet times

\section{$-4-$}

Быд принят новый устав, такте было разрешено на постройку новых мечетей, создание специадьных шкод-медресө ддя подтотовки имамов и цуадзинов. В шкодах были приняты новне програмы, быдо разрешено издать коран и аф̆тиак ( 8 часть корана). Таки образои Ведикая Овтвбрьская содиадистическая рөводюция дада всеи народам оди наковые права, отдедив редигио от государства. По советскоиу закону кахдый грахданин свободно могет исповедывать дюбую редигио, это дичное дедо кахдого. Совегское Правитеньство раврепило среднеазшатски народам (киргизаи, казахамт таджикаи, туркменам, узбекаи. создаяь свое Средне Азиатское духовное Управпение цусудьман.

Мусудъманаи Северного Кавказа и Дагестана было разрешено создать свое Духовное Управдение хусудьман з г.Буйнакск Дагестанской Автономн оћ Республике.

А цусудьмане Авербайдханскои, Армянской, Грузинской ССР соөдинились в Духовное управнөниө цусудьман В $Г$ :Баку Азөрбайдханской Советской Социадистическон рөспубдикө.

На съезде 25-го октября I948 года Духовноө управнөние России подучило название Духовного Управлөния Европейской части ССР и Стбири и туда вкдючидись все цусульмане, хивуие в РСФСР. Украинской, Бөдорусскои, Јатвийской, Литовской ССР.

Все дјховные Управления приняли новые уставы. Руководители әтгх Духовньх Управлений не навначались царским укавом, как әто дедадось во вреия царского правитедьства, а на оборот все цусудьшане, живуцие в Совөтском Союзе посылапт свопх представитедөй для принятия участия о выборе редитиовното вдудитедя Духовньх Упраплений шусудьман. В настоящее время все духовыне Управпения объединягт всех приходов, и управдяит им в редигиовном деде в работе на местах тодько согдасно тариату, ивдарт указы, отвечают на всө вопросы. 
Thus, according to the Sermon, the golden age in the history of the muftiate came after the October Revolution of 1917. In this respect, the Memorandum diverges somewhat from the Sermon, maintaining that the golden period occurred during the existence of independent Muslim states in the Volga-Ural region. Regarding the position of the muftiate under the Soviet regime, the author of the Memorandum is more restrained. This is not only because F. Sattarov and R. Fakhreddin were representatives of different generations of Muslim religious figures, but also because in 1923 both the future of the Soviet government itself and potential changes in the government's confessional policy in relation to Muslims and the Spiritual Administration were unknown.

The narratives discussed above were important not only in order to solve some current problems associated with the functioning of the Spiritual Administration in Ufa. In 1920-1930 some studies appeared whose authors sought to prove that "the version so far prevalent in literature and supported by the Muslim clergy about the persecution of Islam as a religion by the Russian autocracy is false" (Klimovich 2002: 93-133). The most prominent representative among historians professing such views was Lyutsian I. Klimovich, who insisted that the tsarist government did not fight Islam as a religion but only old Islamic administrative bodies, "which did not want to come to terms with Russian domination" (Klimovich 2002: 10). Klimovich describes the Muslim clergy themselves as "agents of autocracy," and through a tendentious selection and interpretation of facts from the history of the muftiate, tries throughout his work $I s-$ lam in Tsarist Russia to present the Muslim clergy as a natural ally of the autocracy in suppressing the masses of peoples traditionally professing Islam (Klimovich 2002: 10). Moreover, Klimovich's oppressors are not only the socalled highest clergy (the mufti, qazis, etc.), but also ordinary ministers of the Islamic religion'. Biased though Klimovich's works are, one thesis repeated throughout the book is obviously correct: "For us . . . the role of tsarism in relation to Islam as a religion is important. From the first steps of the Russian autocracy, this line is expressed in the desire to enlist Islam in its service" (Klimovich 2002: 10). Soviet officials also pretty soon realized that it was important for them not only to rely on the loyal ministers of the Islamic religion to carry out their policies, but also to keep the muftiate in Ufa inviolable, as a structure that would allow them to control the religious life of believers.

${ }^{9}$ There were also some Tatar historians who criticized the muftiate and the clergy. Thus, in particular, a famous Tatar writer and historian Galimjan Ibrahimov wrote about the Muslim clergy: "With its "decrees," metrics, prayers, offered in mosques for the tsar, in particular, with its Spiritual Assembly, muftis, it was firmly soldered to the autocracy (samoderzhavie)." (Ibragimov 1926: 8). 
Bekkin R.I. Narratives on the Origin of the Institution

of the Muftiate among Tatars in Soviet times

\section{SOURCES AND MATERIALS}

Amirkhanov Kh. Tavarikh-e Bulgaria [Bulgarian chronicles]. Moscow: Mardzhani Publ. house, 2010. (In tatar)

Arapov D.Yu. Islam i sovetskoe gosudarstvo (1917-1936). Sbornik dokumentov [Islam and the Soviet State (1917-1936). Collection of documents]. No. 2. Moscow: Mardzhani Publ. house, 2010. (In Russian)

Fakhreddin P. Islamner khakynda khokumet tedbirlere [Government orders relating to Muslims]. Orenburg, 1902. (In tatar)

\section{REFERENCES}

Bekkin R.I. «Ukorotit' khvost nezakonnykh religioznykh deyateley». Ob ideynoi evolyutsii vzglyadov Faizrakhmanova Sattarova na rol' «ofitsial'nogo dukhovenstva» V religioznoy zhizni musul'man Rossii ["Dock the tail of illegal religious igures." The ideological evolution of Faizrakhman Sattarov's views on the role of 'official clergy' in the life of Russian Muslims]. Gosudarstvo, religiya, tserkov' v Rossii i za rubechom, 2018, no. 4, pp. 277-323. (In Russian)

Ibragimov G. Tatary v revolyutsii $1905 \mathrm{~g}$. [Tatars in the Revolution of 1905]. Kazan, 1926. (In Russian)

Kemper M. "Ljucian Klimovič: Der ideologische Bluthund der sowjetischen Islamkunde und Zentralasien literatur" [Ljucian Klimovič: The Ideological Bloodhound of Soviet Islamic Studies and Central Asian Literature]. Asiatische Studien/Études asiatiques 63, 2009, no. 1, pp. 93-133. (In German)

Khamidullin B.L., Izmailov I.L., Izmailov B.I. Istoriya Kazanskogo khanstva v trudakh otechestvennykh istorikov (1920-1950-e gg.) [The History of the Kazan Khanate in the Works of Russian Historians (1920-1950s)]. Naucnyy Tatarstan, 2012, no. 3, pp. 92-113. (In Russian)

Klimovich L. Islam v tsarskoi Rossii [Islam in Tsarist Russia]. Kazan: Iman Publ., 2002. (In Russian)

Malikov R.I. Sotsial'noye polozheniye musul'manskogo dukhovenstva Kazanskoy gubernii [The Social Status of the Muslim Clergy of the Kazan Province in Late $19^{\text {th }}-$ early $20^{\text {th }}$ centuries]. Kazan: Russian Islamic University Publ., 2013. (In Russian)

Rechkina I.A. Musul'manskaya politika rossiyskikh vlastei v kazakhskoy stepi: (konets XVIII v. - 60-e gg. XIX vv.) [Muslim Policy of the Russian Authorities in the Kazakh Steppe: (Late 18th century -60 s of the $19^{\text {th }}$ century)]. Vestnik Omskogo universiteta, 2006, no. 2, pp. 80-84. (In Russian)

Schulze R. A modern history of the Islamic world. London: I.B. Tauris, 2002. (In English)

Turner B.S. Weber and Islam. A critical study. London and New York: Routledge, 2006. (In English)

Yunusova A.B., Azamatov D.D. 225 let tsentral'nomu dukhovnomu upravleniyu musul'man Rossii: istoricheskie ocherki [225 Years to the Central Religious Administration of Muslims of Russia: Historical Essays]. Ufa: Ufa Printing Plant, 2013. (In Russian)

Zagidullin I.K. Predisloviye. Orenburgskoe magometanskoye dukhovnoye sobraniye i dukhovnoye razvitiye tatarskogo naroda v posledney chetverti XVIII - nachale 
$X X v v$. ["Foreword" to the Orenburg Mohammedan Spiritual Assembly and the spiritual development of the Tatar people in the last quarter of the eighteenth and beginning of the twentieth centuries]. Kazan: RT Academy of Sciences Institute of History Publ., 2011, pp. 3-11. (In Russian)

About the author: Renat I. Bekkin is a Doctor Sc. (Economics), Ph.D. in Religious Studies, Cand. Sc. (Law), Professor of the Russian Academy of Sciences, Professor at the Institute of Oriental Studies at the Herzen State Pedagogical University of Russia (St. Petersburg, Russian Federation); Leading Research Fellow at the Institute for African Studies of the Russian Academy of Sciences (30/1 Spiridonovka St., Moscow 123001, Russian Federation); bekkin@mail.ru

Received September 27, $2020 \quad$ Accepted for publication November 05, 2020

Published November 25, 2020

\title{
НАРРАТИВЫ О ПРОИСХОЖДЕНИИ МУФТИЯТА СРЕДИ ТАТАР В СОВЕТСКОЕ ВРЕМЯ
}

\author{
Р.И. Беккин \\ Институт востоковедения РГПУ им. А.И. Гериена \\ Санкт-Петербург, Российская Федерация \\ Институт Африки Российской академии наук \\ Москва, Российская Федерация \\ bekkin@mail.ru
}

Причиной создания института муфтията в 1788 г. было желание государства наиболее эффективным образом контролировать религиозную жизнь мусульман. Правительству казалось более удобным иметь дело с организованной структурой, включенной в систему контролируемых государством религиозных организаций, а не с отдельными, не институционализированными представителями мусульман, которые полагались в основном на свой авторитет среди верующих и не нуждались в легитимации и поддержке со стороны государства. Значительное число мусульманских религиозных деятелей изначально не признали институт муфтията и систему утверждения имамов государством. Однако к середине XIX в. тюркотатарское население Российской империи стало рассматривать духовное собрание в Уфе как институт, охраняющий его национальную идентичность в православном государстве. Таким образом, произошло присвоение муфтията определенной частью мусульманского населения империи. В результате возникла легенда о том, что муфтият как институт исторически существовал у тюрко-татар задолго до того, как они были покорены Москвой.

Первые нарративы о том, что муфтият существовал в Казанском ханстве и был разрушен после завоевания Казани в 1552 г. Иваном Грозным, вероятно, появились в конце XIX в. В советское время эта точка зрения была широко распространена в 1920-1930-е гг. Позже легенда о муфтияте как национальном институте татар подверглась модификации, но главный тезис о том, что муфтият является 
Bekkin R.I. Narratives on the Origin of the Institution of the Muftiate among Tatars in Soviet times

важным инструментом сохранения духовной культуры татарского народа, остался неизменным. Изменения в интерпретации истории института муфтията во многом стали отражением процессов, происходивших в системе советских духовных управлений мусульман в советское время.

Нарратив о муфтияте как исконном национальном институте татар противоречил взглядам ряда советских историков (Л.И. Климовича, М.А. Аршаруни, Х.З. Габидуллина, Г.Г. Ибрагимова и др.). Они рассматривали муфтият исключительно как колониальный институт, навязанный мусульманам и служивший инструментом их порабощения и угнетения.

Ключевые слова: муфтият, Оренбургское магометанское духовное собрание, Ризаэддин Фахреддин, Файзрахман Саттаров, ислам в СССР

Для цитирования: Bekkin R.I. Narratives on the Origin of the Institution of the Muftiate among Tatars in Soviet times // Историческая этнология. 2020. Т. 5, № 2. C. 225-242. https://doi.org/10.22378/he.2020-5-2.225-242

\section{ИСТОЧНИКИ И МАТЕРИАЛЫ}

Амирханов 2010 - Амирханов Х. Таварих-е Булгарийа (Булгарские хроники) / Перевод со старотатарского, вступительная статья и комментарии А.М. Ахунова. М.: Изд. дом Марджани, 2010.

Арапов 2010 - Арапов Д.Ю. Ислам и советское государство (1917-1936). Сборник документов. Вып. 2. М.: Изд. дом Марджани, 2010.

Фәхреддин 1902 - Фәхреддин Р. Исламнар хакында хөкүмәт тәдбирләре. Оренбург, 1902.

\section{НАУЧНАЯ ЛИТЕРАТУРА}

Беккин Р.И. «Укоротить хвост незаконных религиозных деятелей». Об идейной эволюции взглядов Файзрахмана Саттарова на роль «официального духовенства» в религиозной жизни мусульман России // Государство, религия, церковь в России и за рубежом. 2018. № 4. С. 277-323.

Загидуллин И.К. Предисловие // Оренбургское магометанское духовное собрание и духовное развитие татарского народа в последней четверти XVIII - начале XX вв. Казань: Институт истории им. Ш. Марджани АН РТ, 2011. С. 3-11.

Ибрагимов Г. Татары в революции 1905 г. Казань, 1926.

Климович Л. Ислам в царской России. Казань: Иман, 2002.

Маликов Р.И. Социальное положение мусульманского духовенства Казанской губернии. Казань: Российский исламский университет, 2013.

Речкина И.А. Мусульманская политика российских властей в казахской степи: (конец XVIII в. - 60-е гг. XIX в.) // Вестник Омского университета. 2006. № 2. C. $80-84$.

Хамидуллин Б.Л., Измайлов И.Л., Измайлов Б.И. История Казанского ханства в трудах отечественных историков (1920-1950-е гг.) // Научный Татарстан. 2012. № 3. C. 92-113. 
Юнусова А.Б., Азаматов Д.Д. 225 лет Центральному духовному управлению мусульман России: исторические очерки. Уфа: Уфимский полиграфкомбинат, 2013.

Kemper M. "Ljucian Klimovič: Der ideologische Bluthund der sowjetischen Islamkunde und Zentralasienliteratur". Asiatische Studien/Études asiatiques 63, 2009, no. 1, pp. 93-133.

Schulze R. A modern history of the Islamic world. London: I.B. Tauris, 2002.

Turner B.S. Weber and Islam. A critical study. London and New York: Routledge, 2006.

Сведения об авторе: Беккин Ренат Ирикович -доктор экономических наук, $\mathrm{PhD}$ in Religious Studies, кандидат юридических наук, профессор PAH, профессор Института востоковедения РГПУ им. А.И. Герцена (Санкт-Петербург, Российская Федерация); ведущий научный сотрудник Института Африки РАН (123001, ул. Спиридоновка, 30/1, Москва, Российская Федерация); bekkin@mail.ru 